\title{
THE CREATIVE FUNCTION OF WATER IN THE FORMATION OF THE WORLD AROUND US
}

\author{
S. L. Shvartsev 1,2 \\ 1 Tomsk Division of A.A. Trofimuk Institute of Petroleum Geology and Geophysics, Siberian Branch of RAS, \\ Tomsk, Russia \\ 2 Tomsk Polytechnic University, Tomsk, Russia
}

\begin{abstract}
The article is focused on the evolution mechanism of the 'inert' and living world around us, which is determined by the creative function of water. Water and igneous rocks of basic and ultrabasic compositions create an abiogenic dissipative system that never reaches an equilibrium and therefore is capable of maintaining its continuous, strictly directed, geologically long-term development and the formation of numerous new minerals that are paragenetically associated with specific geochemical types of water. This system is equilibrium-nonequilibrium. It develops in a thermodynamic area, far from an equilibrium. It is non-linear, irreversible, and internally contradictory. In this system, water has the creative function: the hydrolysis mechanism continuously dissolves some minerals, with which the system is not in equilibrium, and, at the same time, creates others minerals, with which there is an equilibrium, including the mineral that have been absent on our planet. After the occurrence of photosynthesis, the system was supplemented with organic compounds and developed into the 'water-rock-gas-organic matter' system. The mechanisms of this system were generally described by V.I. Vernadsky, and we suggest to name this system after him. The Vernadsky system had not only repeatedly became more and more complicated, but acquired the capability of creating more complex organic compounds from simple carbohydrates, such as proteins, lipids, more complex carbohydrates, hemoglobin etc. With time, these components developed into living organisms. Regardless of the repeated complication of the system, the basic mechanisms of its evolution remain essentially the same, and water has preserved and enhanced its creative function through dissolving simple compounds and creating more complex ones. An important factor in the continuous complication of the system is the natural water cycle.
\end{abstract}

Key words: environment; global evolution; natural water; hydrogenous mineral complex; thermodynamic equilibrium; equilibrium-nonequilibrium; complication mechanism; creative function of water; V.I. Vernadsky system

\section{RESEARCH ARTICLE}

Received: October 10, 2018

Статья подготовлена по материалам доклада, представленного на Всероссийском совещании по подземным водам Востока России (Новосибирск, 18-24 июня 2018 г.)

For citation: Shvartsev S.L., 2018. The creative function of water in the formation of the world around us. Geodynamics \& Tectonophysics 9 (4), 1275-1291. doi:10.5800/GT-2018-9-4-0395.

Для цитирования: Шварцев С.Л. Созидательная функция воды в формировании окружающего мира // Геодинамика и тектонофизика. 2018. Т. 9. № 4. С. 1275-1291. doi:10.5800/GT-2018-9-4-0395. 


\title{
СОЗИДАТЕЛЬНАЯ ФУНКЦИЯ ВОДЫ В ФОРМИРОВАНИИ ОКРУЖАЮЩЕГО МИРА
}

\author{
С.Л. Шварцев 1,2 \\ ${ }^{1}$ Томский филиал Института нефтегазовой геологии и геофизики им. А.А. Трофимука СО РАН, \\ Томск, Россия \\ ${ }^{2}$ Национальный исследовательский Томский политехнический университет, Томск, Россия
}

\begin{abstract}
Аннотация: В статье раскрывается механизм эволюции окружающего нас «косного» и живого мира, который обусловлен созидательной функцией воды. Показано, что вода с магматическими породами основного и ультраосновного состава образует абиогенную диссипативную систему, которая никогда не приходит в равновесие и поэтому способна непрерывно, строго направленно, геологически длительно развиваться с формированием многочисленных новых вторичных минералов, парагенетически ассоциирующих с определенными геохимическими типами воды. Эта система является равновесно-неравновесной, развивается в термодинамической области, далекой от равновесия, является нелинейной, необратимой, внутренне противоречивой. Созидательная функция воды в этой системе заключается в том, что она непрерывно по механизму гидролиза растворяет одни минералы, с которыми неравновесна, но тут же создает другие, с которыми имеется равновесие, включая и такие, которых на нашей планете раньше не было. После появления фотосинтеза эта система дополнилась органическими соединениями и превратилась в систему вода - порода - газ - органическое вещество, механизмы действия которой были в общих чертах раскрыты В.И. Вернадским и которую мы предложили называть его именем. Тем самым система В.И. Вернадского не только многократно усложнилась, но и получила возможность создавать из простых углеводов более сложные органические соединения, включая белки, липиды, углеводы, гемоглобин и т.д. В последующем из этих компонентов возникли живые организмы. Несмотря на многократное усложнение системы, основные механизмы ее эволюции принципиально остались такими же, а вода сохранила и приумножила свою созидательную функцию путем растворения простых соединений и создания более сложных. Показано также, что важным фактором непрерывного усложнения системы выступает круговорот воды.
\end{abstract}

Ключевые слова: окружающий мир; глобальная эволюция; природная вода; гидрогенно-минеральный комплекс; термодинамическое равновесие; равновесно-неравновесная система; механизм усложнения; созидательная функция воды; система В.И. Вернадского

\section{1. ВВЕДЕНИЕ}

Почему изменяется окружающий нас мир? Как идет его усложнение? Какие силы движут его эволюцию? Как возникла жизнь? Эти и многие другие вопросы не дают покоя ученым уже в течение нескольких тысяч лет. Еще древние мыслители Эллады, заложившие основы диалектического мышления, пытались найти ответы на эти вопросы. Уже тогда были сформулированы основополагающие идеи о единстве окружающего мира. Под единством подразумевалось наличие одной (главной) субстанции, которая создает этот мир. Но какая именно субстанция делает это - взгляды разошлись: Фалес из Милета считал, что вода есть начало всех вещей, их материальной сущности, которые в воду и превращаются; Гераклит из Эфеса такую же функцию отводил огню. С тех пор эти две точки зрения продолжают существовать, не находя примирения.

Периодически споры сторонников этих двух генеральных линий о путях развития окружающего мира разгорались с особой силой. Так было, в частности, в конце XVIII - начале XIX в., когда дискуссия вспыхнула особенно остро между нептунистами (сторонниками доминирующей роли воды) и плутонистами (сторонниками огня). Лидером первых был немецкий ученый А.Г. Вернер (1749-1817), лидером вторых - шотландский ученый Дж. Геттон (1726-1797).

Среди нептунистов своими новаторскими идеями выделялся французский зоолог Ж.-Б. Ламарк (1744-1829), который в 1802 г. издал книгу «Hydrogéologie». В этой книге он пытался раскрыть роль воды в развитии и становлении Природы (в те времена писали с большой буквы). По сути, в этом издании Ж.-Б. Ламарк наиболее полно изложил основы своих представлений о нептунизме как научном мировоззрении [Shvartsev, 2013a]. Позже он более полно развил свои взгляды в «Философии зоологии» (1809 г.).

Одна из важнейших задач, поставленных Ж.-Б. Ламарком, состояла в поиске силы, которая обеспечивает изменение Природы, ее усложнение, 
эволюцию. Решая эту грандиозную проблему он, к своему удивлению, не обнаружил в окружающих «косных» объектах никаких созидательных процессов, только разрушительные. Тогда он предположил, что такая жизненная сила (pouvoir de la vie) имеет место только в живых организмах, но она науке неизвестна. Этим самым Ж.-Б. Ламарк возвел демаркационную границу между живой и «косной» материей: в первой эволюция есть, во второй ее нет. Позже Ч. Дарвин заменил жизненную силу Ламарка случайными процессами естественного отбора, который не имеет ни физического, ни химического смысла, и получил поддержку многих ученых.

В XX в. физики в лице Э. Шрёдингера (18871961) поддержали идею наличия эволюции только в живой материи. В 1944 г. он опубликовал книгу, которая уже в 1947 г. была переведена на русский язык и неоднократно переиздавалась [Schrödinger, 1972]. В этой книге он разработал концепцию зависимости усложнения любой системы от соотношения потоков энтропии из системы в среду и обратно. Живые системы, по его мнению, всегда являются неравновесными и никогда, кроме смерти, не переходят в инертное (равновесное) состояние. Неравновесность они сохраняют за счет среды, из которой непрерывно черпают необходимую неупорядоченность или неэнтропию. Чтобы жить, пишет Шрёдингер, организм должен постоянно извлекать из окружающей его среды отрицательную энтропию, «которая представляет собой нечто весьма положительное... Отрицательная энтропия - вот то, чем организм питается» [Schrödinger, 1972]. В отличие от живой материи, неживая, по Э. Шрёдингеру, очень быстро приходит в равновесие с окружающей средой, потому что неспособна накапливать энтропию из последней.

Концепция Э. Шрёдингера о том, что усложнение эволюции определяется внешней средой, была признана фактически всей наукой. И хотя полное единство в науке не было достигнуто: развивались разные модификации течения эволюции [Khaitun, 2009], основной подход к эволюции как функции только живой материи, главенствующей роли естественного отбора и случайного ее характера сохранился до сих пор. Поскольку вода - это часть неживого мира, она не попала в число эволюционирующих элементов. Так великий Ж.-Б. Ламарк, будучи ярым сторонником нептунизма, основателем учения об эволюции, фактически исключил воду из эволюционного процесса, протекающего на нашей планете.

Положение Ламарка об отсутствии эволюции в неживой материи казалось настолько убедительным, что даже гениальный ученый В.И. Вернадский придерживался такого же мнения. И хотя он придавал огромное значение взаимодействию воды с горными породами, газами и органическим веществом, фактически показывая, что оно носит характер эволюции, тем не менее никогда не говорил об эволюции в неживой материи. Среди главных стихий окружающего мира В.И. Вернадский [Vernadsky, 2003] отводил совершенно особую роль воде с ее многочисленными необычными свойствами, указывал на многие механизмы преобразования ею окружающего мира, показывал ее «всюдность»и многоликость. Но и сегодня это уникальное соединение остается на задворках эволюционных теорий. Великая роль воды ни в геологической, ни в биологической эволюции современной наукой не раскрыта.

Яркий пример этому - книга известного английского биолога, популяризатора науки Р. Докинза, в которой он пишет: «Эволюция путем естественного отбора - по сей день единственный известный нам способ, которым из простого начала получается сложное» [Dawkins, 2012, c. 429]. Но с этим трудно согласиться [Shvartsev, 2014]. Р. Докинз не находит и начало эволюции: «... свидетельств относительно момента начала эволюции на планете у нас нет. Это могло быть событие невероятной редкости: ведь произойти оно должно было всего однажды, и, насколько мы знаем, так это и есть. Более того, возможно, оно произошло единственный раз во Вселенной» [Dawkins, 2012, c. 429].

Следовательно, эволюция - это случайное явление, начало и механизм которого неизвестны. Но возможно ли такое? Миллиарды органических соединений, клеток, бактерий, растений, животных, людей, красота мира, разум человека, самоорганизация материи, сама жизнь - случайные «прохожие», готовые в любой момент оставить этот мир? Разве можно в это поверить в эпоху ноосферы, в век небывалого развития науки и здравого смысла?!

Особенно поражает то, что до сих пор наука считает эволюцию, а значит и жизнь, случайным явлением, которое совершается без влияния какойлибо внутренней силы, непрерывно усложняющей окружающий мир. Некоторые ученые считают случайности строго закономерным явлением. Например, Е.В. Кунин в своей нашумевшей книге [Kunin, 2014] обосновывает гипотезу, согласно которой случайности имеют свои закономерности на разных этапах эволюции, определяемые разными факторами. Относительно происхождения жизни в соответствии с гипотезой МММ (модель мира многих миров) Е.В. Кунин полагает, что «в бесконечной мультивселенной с конечным числом различных макроскопических историй (так что каждая повторяется бесконечное число раз) случайное появление даже очень сложных систем не только возможно, но и неизбежно» (курсив мой - С.Ш.) [Kunin, 2014, c. 1038]. Эту позицию автор обосновывает матема- 
тическими методами, но они не прибавляют ей убедительности.

Не избежал наличия случайностей в своих построениях эволюционной теории окружающего мира, включая социальные системы, и Н.Н. Моисеев [Moiseev, 1998]. Развивая идеи глобального эволюционизма, он рассматривал окружающий мир как результат длительного развития от простого к сложному путем самоорганизации. Но механизм самоорганизации, по его мнению, не остается неизменным, а меняется по мере развития эволюционных процессов. При этом он полагал, что эволюция протекает через множество случайных явлений, которые образуют своеобразную закономерность. По его мнению, естественный отбор обеспечивает приспособление живых организмов к окружающей среде, а появление Человека привело к обратному: приспособлению окружающего мира к людям. В то же время он неоднократно подчеркивал, что живое вещество - главный фактор эволюции окружающего мира. Он пишет: «Сегодня мы можем говорить о том, что весь лик Земли, все ее ландшафты, все осадочные породы, в том числе и древнейшие граниты и гнейсы, - результат деятельности живого вещества» [Moiseev, 1998, c. 112].

Геологи так же активно присоединились к идее наличия эволюции в разных геологических процесcax, но внутренних механизмов этого явления не нашли. Принято считать, что эволюция последних протекает под действием внешних факторов, среди которых называют снижение во времени интенсивности мантийного теплового потока, увеличение массы континентальной земной коры, сокращение площадей с мобильным тектоническим режимом, нарастание интенсивности окислительных процессов, изменение во времени состава атмосферы, возрастание роли живой материи и т.д. [Yanshin, 1993].

Приведенный краткий обзор показывает, что современная наука в основном рассматривает эволюцию как прерогативу только живой материи, которая появилась случайно, но захватила весь окружающий мир, включая и «косные» системы. Никакой особой роли вода в эволюционных процессах окружающего мира не играет, а является одним среди множества случайных факторов, которые определяют ход эволюции. Но при этом забывается главная проблема: эволюция (образование сложностей) без участия воды невозможна [Shvartsev, 2014, 2017a].

Иные подходы к эволюции развивает синергетика, которая пытается расширить понятие глобальной эволюции путем поиска единых основ усложнения живых и неживых систем. Базовым представлением этой науки является то, что в открытых неравновесных и необратимых системах могут возни- кать и устойчиво развиваться локализованные диссипативные структуры, в нелинейных свойствах которых заключены потенциальные спектры эволюционных процессов и перестройки самих этих структур. Каждая структура, которая эволюционирует во времени, обладает набором собственных функций эволюции в нелинейных средах и способна к устойчивой организации процессов усложнения в таких системах. И все это в одинаковой степени для живой и неживой материи [Nicolis, Prigogine, 1989; Knyazeva, Kurdyumov, 2005; и дp.].

Важной особенностью эволюции диссипативных структур, по мнению ученых, развивающих синергетику, является обязательное наличие этапа неустойчивости, в течение которого система выбирает новое направление своего развития. Этап неустойчивости, по И. Пригожину, является исключительно важным, поскольку выступает условием стабильного и динамического развития диссипативных структур. По его мнению, только системы, далекие от равновесия и находящиеся в состоянии неустойчивости, способны самоорганизовываться и развиваться в направлении усложнения. Устойчивость и равновесность ведут эволюцию в тупик, а неустойчивость и неравновесность - к усложнению эволюционных процессов.

По И. Пригожину, состояние неустойчивости системы всегда возникает вблизи точки бифуркации, в которой система выбирает новый путь развития. Такой выбор пути дальнейшей эволюции предопределен наличием в открытых нелинейных средах особого поля путей возможного их развития. Нелинейная система в точке бифуркации совершает блуждания по полю возможного развития и каждый раз случайно выбирает лишь один из возможных путей. При этом решающими факторами, влияющими на выбор пути, могут оказаться случайные малые флуктуации внешней среды.

Снова мы оказываемся в плену случайных малых флуктуаций даже не самой системы, а внешней среды, влияющей на эволюцию конкретной системы. По мнению И. Пригожина и И. Стенгерса [2003], при изменении констант внешней среды меняется некий управляющий параметр системы, который и при достижении определенных критических значений не может обеспечить устойчивость термодинамической ветви системы, поэтому наступает этап ее бифуркации и система получает как минимум два возможных новых пути развития.

Таким образом, синергетика, как междисциплинарная наука, безусловно, формирует новое мышление о связи живого с неживым, устанавливает мостики, ведущие к пониманию единого начала эволюционных преобразований окружающего нас мира, пытается найти некие универсальные закономерности эволюции и самоорганизации веще- 
Т а б л и ц а 1. Минимально необходимое количество химических элементов или их соединений в растворе для образования некоторых вторичных минералов при $\mathrm{pH}=7.0$ и $\mathrm{T}=25^{\circ} \mathrm{C}$

$\mathrm{T}$ a $\mathrm{b}$ l e 1 . The minimum required number of chemical elements or their compounds in the solution for the formation of secondary minerals at $\mathrm{pH}=7.0$ and $\mathrm{T}=25^{\circ} \mathrm{C}$

\begin{tabular}{|c|c|c|c|c|c|c|c|c|}
\hline \multirow[t]{2}{*}{ Минерал } & \multirow[t]{2}{*}{$\begin{array}{l}\text { Реакция образования вторичного } \\
\text { минерала }\end{array}$} & \multirow[t]{2}{*}{$\lg K$} & \multicolumn{6}{|c|}{$\begin{array}{l}\text { lg минимально необходимой активности } \\
\text { химических элементов, моль/л }\end{array}$} \\
\hline & & & $\mathrm{Fe}^{3+}$ & $\mathrm{Al}^{3+}$ & $\mathrm{CO}_{3}{ }^{2-}$ & $\mathrm{Ca}^{2+}$ & $\mathrm{Mg}^{2+}$ & $\mathrm{Si}^{4+}$ \\
\hline Гиббсит & $\mathrm{Al}^{3+}+3 \mathrm{OH}^{-}=\mathrm{Al}(\mathrm{OH})_{3}$ & -37.72 & - & -16.7 & - & - & - & - \\
\hline Гетит & $\mathrm{Fe}^{3+}+3 \mathrm{OH}^{-}=\mathrm{FeOOH}+\mathrm{H}_{2} \mathrm{O}$ & -38.81 & -11.8 & - & - & - & - & - \\
\hline Сидерит & $\mathrm{Fe}^{2+}+\mathrm{CO}_{3}^{2-}=\mathrm{FeCO}_{3}$ & -10.89 & $-6.19^{x}$ & - & -4.8 & - & - & - \\
\hline Доломит & $\mathrm{Ca}^{2+}+\mathrm{Mg}^{2+}+2 \mathrm{CO}_{3}{ }^{2-}=\mathrm{CaMg}\left(\mathrm{CO}_{3}\right)_{2}$ & -17.09 & - & - & -4.8 & -3.68 & -3.81 & - \\
\hline Каолинит & $2 \mathrm{Al}^{3+}+2 \mathrm{H}_{4} \mathrm{SiO}_{4}+6 \mathrm{OH}^{-}=\mathrm{Al}_{2} \mathrm{Si}_{2} \mathrm{O}_{5}(\mathrm{OH})_{4}+5 \mathrm{H}_{2} \mathrm{O}$ & -79.39 & - & -16.7 & - & - & - & -4.0 \\
\hline Са-монтмориллонит & $\begin{array}{l}0.167 \mathrm{Ca}^{2+}+2.33 \mathrm{Al}^{3+}+3.67 \mathrm{H}_{4} \mathrm{SiO}_{4}+7.32 \mathrm{OH}^{-}= \\
=\mathrm{Ca}_{0.167} \mathrm{Al}_{2.33} \mathrm{Si}_{3.67} \mathrm{O}_{10}(\mathrm{OH})_{2}+10 \mathrm{H}_{2} \mathrm{O}\end{array}$ & -89.27 & - & -11.7 & - & -3.68 & - & -2.8 \\
\hline
\end{tabular}

ства, но и она не обходится без случайностей. Это происходит потому, что синергетика, как и многие другие науки, не учитывает совершенно особую роль воды в создании и преобразовании Земли, сущность и механизмы процессов взаимодействия воды с горными породами, газами, живой и мертвой органикой. Иначе говоря, то гидрогеохимическое направление, которое развивал великий В.И. Вернадский, остается до сих пор до конца неосознанным. Вода - это совершенно особая материя планеты, которая пронизывает все ее вещество и, непрерывно перестраивая его, создает новый мир. Взаимодействие воды с веществом, начиная с горной породы, носит особый характер и развивается без случайностей [Shvartsev, 2017b].

\section{2. ВНУТРЕННЯЯ ЭВОЛЮЦИЯ СИСТЕМЫ ВОДА - ПОРОДА - ГАЗ}

В наше время общепризнано, что Земля и другие планеты Солнечной системы изначально образованы базальтами, состоящими в основном из магматических алюмосиликатов $\mathrm{Ca}, \mathrm{Mg}$ и $\mathrm{Fe}$. Именно с минералами этого типа (анортит, битовнит, лабрадор, форстерит, фаялит, энстатит, ферросилит, диопсид и др.) на ранних стадиях эволюции Земли началось взаимодействие воды. К сожалению, продолжительное время считалось, что такое взаимодействие не может долго продолжаться, поскольку растворимость алюмосиликатов очень мала и быстро наступает равновесие с ними водного раствора. И только в последнее время нам удалось показать, что все наоборот: равновесие природной воды с такими минералами не достигается никогда [Shvartsev, 1998, 2010, 2015; Shvartsev et al., 2007, 2017; Plyusnin et al., 2013].
Причина этого заключается в том, что поступающие из базальтов в раствор химические элементы связываются образующимися в этой системе вторичными минералами иного состава, среди которых гидроксиды, карбонаты, глины, цеолиты, хлориты, слюды и т.д. Все эти вторичные минералы, постоянно связывая растворяемые элементы, выступают геохимическими барьерами на пути установления равновесия подземных вод с минералами базальтов.

Взаимодействие воды с базальтами происходит по механизму гидролиза, т.е. непосредственно в химической реакции, и при вхождении молекул воды или продуктов их диссоциации в кристаллическую решетку вторичных минералов. Последние всегда содержат те или иные составляющие воды: $\mathrm{H}^{+}, \mathrm{OH}^{-}$, $\mathrm{H}_{2}, \mathrm{O}_{2}, \mathrm{H}_{3} \mathrm{O}^{+}$, электроны и т.д., поэтому вода не просто среда, в которой протекает реакция гидролиза, а непосредственный участник самого процесса формирования всех вторичных минералов. Благодаря наличию компонентов воды в составе таких минералов, последние формируются при очень низких содержаниях исходных элементов в растворе (табл. 1). Это означает, что растворение водой базальтов приводит практически одновременно к образованию новых минералов принципиально иного состава: гиббсита, каолинита, иллита, хлорита, кальцита и т.д. Последнее исключительно важно, так как знаменует собой начало созидательной функции воды, заключающейся в формировании принципиально новых для окружающего мира минеральных соединений и воды иного состава.

Приведем конкретный пример. Константа реакции образования гиббсита равна 10-37.72 (табл. 1). Следовательно, при $\mathrm{pH}=7.0$ для насыщения водного раствора этим минералом и его образования необходима минимальная активность $\mathrm{Al}^{3+}$ - всего 
10-16.7 моль/л, т.е. нанограммовые содержания этого элемента. Вода, которая попадает в базальты, получает такое количество этого элемента практически мгновенно (в течение первых суток при обычной температуре). Такие же низкие содержания $\mathrm{Fe}^{3+}$ требуются и для образования его оксидных минералов. Факт образования латеритов при низких концентрациях этих элементов установлен нами в Гвинее еще в 60-х годах прошлого века [Shvartsev, 1972, 1976], а позже и многими другими учеными [Tardy, 1969, 1993]. Для образования глинистых минералов, карбонатов и т.д. также требуются незначительные содержания элементов в воде (миллиграмовые количества, табл. 1). Подробно все эти вопросы описаны ранее [Shvartsev, 1998, $2008 b$ и дp.].

Понимание роли этих очевидных фактов долгое время сдерживалось отсутствием данных о равновесии подземных вод с алюмосиликатными минералами. Но с появлением книги Р.М. Гаррелса и Ч.Л. Крайста «Растворы, минералы, равновесия» в 1965 г. на английском языке [Garrels, Christ, 1965], а в 1968 г. на русском этот барьер был полностью снят, открылись принципиально новые возможности для изучения механизмов взаимодействия воды с алюмосиликатными горными породами.

Проведенные нами многочисленные расчеты равновесия реальных подземных вод зоны гипергенеза с разнообразными минералами горных пород для многих регионов мира показали, что система вода - порода является равновесно-неравновесной: вода всегда неравновесна с одними минералами, которые она медленно, но непрерывно растворяет, но одновременно она равновесна с другими минералами, которые она формирует. При этом состав формирующихся вторичных минералов, а соответственно и их тип меняются в строгой парагенетической ассоциации с изменением состава воды по законам термодинамики [Shvartsev, 1978].

Оказалось, что система вода - алюмосиликаты является внутренне противоречивой, способной к непрерывному геологически длительному взаимодействию с образованием целой гаммы вторичных минералов и многочисленных геохимических типов воды. При этом внутренняя противоречивость этой системы со временем не исчезает, а сохраняется до тех пор, пока не исчезнет либо вода, либо порода. Позже этот принцип был подтвержден и распространен на более глубокие горизонты Земли [Shvartsev, 1991]. Было показано, что равновеснонеравновесное состояние системы вода - порода газ сохраняется в пределах всей земной коры вплоть до $400{ }^{\circ} \mathrm{C}$ и солености до 600 г/л. Из этого факта нами сделан вывод, что равновесно-неравновесное состояние - это фундаментальное свойство рассматриваемой системы, которое отражает ее внутреннюю сущность, определяемую особенностями строения воды и алюмосиликатов, т.е. внутренними свойствами этих соединений, без которых они не могут существовать. Суть внутренней эволюции заключается в непрерывном стремлении воды растворять эндогенные минералы и формировать новые из водного раствора. При этом важно, что в природе нет сил, которые могли бы остановить это взаимодействие, поскольку оно составляет ее внутреннюю сущность [Shvartsev, 2012].

Вода растворяет базальты потому, что таково ее строение, состав и структура, которые несовместимы со строением базальтов. Именно особенности внутреннего строения воды определили сущность и характер ее взаимодействия с этими и другими породами, которое породило абиогенную эволюцию минерального вещества.

Тем самым нами впервые в геологической науке был выявлен механизм внутренней эволюции в неживой материи, независимый от внешних факторов, установлено, что система вода - порода относится к типу диссипативных, развивается вдали от равновесия, является нелинейной, необратимой и всегда способна не случайно, а по строгим законам термодинамики непрерывно формировать принципиально новые минеральные соединения, совершенно непохожие на исходные, растворяемые водой, включая более сложные [Shvartsev, 2001, 2007, $2008 a, 2009,2012,2014,2017 b]$. При этом вода выступает не просто растворителем одних минералов, она переводит их химические элементы в активное состояние, выступает средой, в которой химические элементы из разных минералов могут встречаться и, взаимодействуя друг с другом, формировать новые соединения, в решетку которых обязательно входят молекулы воды или их части.

Вторым препятствием для понимания механизмов эволюции в системе вода - алюмосиликаты долгое время являлось представление о том, что эндогенные минералы превращаются в другие путем твердофазной трансформации кристаллической решетки по диффузионному механизму. Согласно этой модели растворение эндогенных минералов контролируется диффузией компонентов раствора через поверхностный слой. Последний мог представлять из себя выщелоченный остаточный каркас первичного минерала или вторичный минерал, аморфный или кристаллический, осажденный из раствора и т.п. Близка к диффузионной и кинетическая гипотеза растворения алюмосиликатов, согласно которой трансформация исходного минерала определяется не диффузией ионов, а реакциями на поверхности растворяемого минерала, которые обеспечивают отрыв отдельных его атомов и перевод их в раствор [Alekseev, 2002; Alekseev et al., 2005]. Но ни одна из этих гипотез не могла 
объяснить, почему формируются разные вторичные минералы и какова природа последовательности их образования. Считалось, что все определяет состав исходной породы.

К сожалению, современной наукой забыто старинное обобщение алхимиков - Corpora non agunt nisi solute (тела не действуют, если не растворены), которое, по мнению В.И. Вернадского, «очень ярко и точно выражает черту химии земной коры» [Vernadsky, 2003, c. 114]. Но постепенно удалось решить и эту проблему. Так, еще в 1937 г. И.Д. Седлецкий [Sedletsky, 1937] опубликовал результаты своих экспериментов по синтезу кристаллического монтмориллонита из водного раствора кремния и алюминия при обычных температурах. Идею новосинтеза глинистых минералов в почвах активно поддерживал и развивал Б.Б. Полынов [Polynov, 1956]. Позже в СССР стали появляться отдельные статьи, доказывающие, что глинистые минералы - это продукт синтеза разных ионов в водном растворе. Так, например, В.И. Финько с соавторами на основании данных по изучению глинистых минералов в каолиновых корах выветривания электронномикроскопическим методом вакуумного декорирования пришли к выводу, что «ростовые особенности новообразованных глинистых минералов и их взаимоотношения с исходными минералами позволяют однозначно (выделено нами - С.Ш.) считать, что глинистые минералы формировались из раствора в условиях свободной кристаллизации в полостях растворения исходных минералов» [Fin'ko et al., 1980, c. 197]. Такие примеры можно продолжать.

Некоторые иностранные ученые тоже давно развивали идеи новосинтеза вторичных минералов. Так, американский исследователь У.Д. Келлер в 1957 г. обосновал идею, что конечный результат выветривания определяется не составом породы, а типом физико-химической среды. Он писал: «... поэтому было бы правильнее и обоснованнее говорить о продукте среды выветривания, чем о конечном продукте выветривания» [Keller, 1963, с. 155]. Конечно, в то время он не мог осознать, что среда это тоже продукт взаимодействия в системе вода порода - газ - органическое вещество, хотя в работах В.И. Вернадского [Vernadsky, 2003] это положение было обосновано еще в 30-х годах XX в. Идеи У.Д. Келлера поддержал и немецкий геохимик К.В. Корренс [Correns, 1961], который пришел к выводу, что конечный результат выщелачивания это полное растворение исходного алюмосиликата, а не твердофазное стадийное превращение его в глинистые минералы. По его авторитетному мнению, неоднократно выдвигавшаяся гипотеза о том, что при растворении алюмосиликатов происходит простой обмен щелочных элементов на ион водо- рода, является неверной, так как кристаллическая решетка при этом разрушается полностью, а не просто трансформируется.

Большой вклад в изучение механизмов выветривания в обсуждаемом нами аспекте внесли французские геохимики, доказавшие, что в корах выветривания многие вторичные минералы образованы из элементов водного раствора путем новосинтеза и потому названы новосинтезированными [Millot, 1964; Pedro, 1964; Tardy, 1969, 1993; Paquet, 1970]. В частности, Ж. Педро на большом экспериментальном материале показал, что химические элементы, переходящие в раствор при выветривании, формируют не только карбонаты и соли, как считалось раньше, но и глинистые минералы, которые тем самым получили статус сложных солей.

К еще более четкому выводу по характеру превращения одного минерала в другой в процессе гидролиза пришли американские геохимики Дж.P. О’Нейл и Х.P. Тэйлор. Проведя эксперименты по катионному обмену и фракционированию изотопов кислорода между щелочными полевыми шпатами и хлоридным раствором, они показали, что полученные результаты нельзя объяснить только диффузионным механизмом и сделали вывод, что для образования нового минерала каждая часть растворяемого кристалла должна «переплыть реку раствора» [O’Neil, Taylor, 1967, c. 1434].

Между тем эксперименты по растворению алюмосиликатных минералов непрерывно продолжались в разных средах при разных температурах с различными минералами во многих развитых странах. Применяемая техника совершенствовалась, новые данные накапливались и привели к убедительным результатам. Было установлено, что взаимодействие воды с алюмосиликатами протекает в два этапа: 1) растворение одного минерала и 2) образование другого, отличающегося от растворяемого. Таких работ в настоящее время появилось много [Alekseyev et al., 1997; Putnis, 2002; Hellman et al., 2003; Fu et al., 2009; Zhang, Lüttge, 2009; Zhu et al., 2010; Harlov et al., 2011; Upadhyay, 2012; Lu et al., 2015; и др.].

Приведем несколько цитат, подтверждающих ведущий вывод таких исследований. Так, В.А. Алексеев в одной из своих работ прямо пишет: «Инконгруэнтное растворение минералов контролируется не диффузией в твердом теле, а реакциями растворения первичных минералов и осаждения вторичных. Об этом свидетельствует образование ямок травления на поверхности первичных минералов и рост вторичных минералов в виде отдельных кристаллов, резкие границы между первичным и вторичным минералами» [Alekseev et al., 2005, c. 65]. A вот цитата из статьи американских ученых Ч. Зу и П. Лю: «Пионерные работы Г.К. Хелгесона и его со- 
ратников [Garrels, Mackenzie, 1967; Helgeson, 1968; Helgeson et al., 1969, 1984; Aagaard, Helgeson, 1982; Helgeson, Murphy, 1983] по моделированию гидролиза полевого шпата как процесса двойной реакции растворения и осаждения трансформировали изучение взаимодействия воды с горными породами в количественную науку и открыли новые поля деятельности для геохимии на ближайшие десятилетия» [Zhu, Lu, 2009, c. 3191]. Такие выводы можно продолжать. Таким образом, взаимодействие воды с эндогенными алюмосиликатами заключается в практически одновременном протекании двух разных стадий: 1) растворения исходных минералов эндогенного генезиса и 2) осаждения вторичных минералов, состав и структура которых строго определяются параметрами водной среды, включая строение молекулы воды и структуру водного раствора. Именно гармония новых минеральных образований с водной средой делает их стабильными, способными расти во времени и пространстве, противостоять флуктуациям параметров внешней среды. Такая модель подтверждается и данными по характеру равновесия подземных вод с алюмосиликатами: вода всегда неравновесна с минералами первой стадии взаимодействия, которые постоянно растворяются, но равновесна с минералами 2-й стадии, которые поэтому и формируются.

Наличие одновременно двух стадий растворения и осаждения в рассматриваемой системе обеспечивает непрерывное изменение состава воды. Дело в том, что не все химические элементы, поступающие в раствор, одновременно связываются вторичными минералами, а только их незначительная доля. В то время как одна часть элементов переходит в твердую фазу, другая продолжает концентрироваться в растворе до строго определенного уровня, после достижения которого и некоторая другая часть элементов переходит в осадок и т.д. Со временем связываемых вторичной минеральной фазой элементов становится больше, а концентрируемых меньше. Тем самым разнонаправленные процессы растворения и осаждения обеспечивают непрерывное изменение состава водного раствора. А это, в свою очередь, приводит к последовательному образованию новых, но не случайных, а строго термодинамически обусловленных вторичных минералов. Эти процессы протекают в рамках жесткого закона: каждый последующий вторичный минерал образуется из раствора иного состава относительно предыдущего. Для изменения раствора требуется время, необходимое для накопления в нем определенного количества нужных для образования новой твердой фазы химических элементов. Отсюда возникает прерывистый характер образования вторичных минералов. При этом состав водного раствора, а значит, и си- стема в целом непрерывно усложняются [Shvartsev, 2014, 2017b].

Если к этому добавить, что среди вторичных минеральных образований, формируемых водой, имеются и такие, которые аккумулируют солнечную энергию и соответственно уменьшают энтропию системы [Shvartsev, 2003, 2009, 2017b], то становится понятным, что и «косные» системы способны к эволюции.

Следовательно, налицо наличие эволюции в неживой материи, суть которой состоит в следующем: неравновесно-равновесная, внутренне противоречивая система вода - эндогенные алюмосиликаты обеспечивает постоянное растворение одних минералов и формирование других с непрерывным усложнением состава и структуры водного раствора, глубокую дифференциацию химических элементов и строгую последовательность целой гаммы новых вторичных минералов, комплекс которых в тесной связи с геохимическими типами воды положил начало формированию на нашей планете новых гидрогенно-минеральных комплексов, а значит, и новой окружающей среды [Shvartsev, 2008a]. Таков результат особого внутреннего взаимодействия в системе вода - алюмосиликаты, который положил начало созидательной функции воды. Последняя состоит в непрерывном создании из менее простых соединений все более сложных вторичных продуктов, включая и такие, которых ранее на Земле не было. Именно вода, благодаря своим многочисленным особым свойствам [Vernadsky, 2003; Rassadkin, 2008], создала механизм преобразования и усложнения окружающего мира, условия для устойчивой и необратимой эволюции на нашей планете [Shvartsev, 2010, 2013b, 2016]. Созидательная функция воды на этом не закончилась, а продолжилась с появлением фотосинтеза на новом, еще более сложном, этапе.

\section{3. НОВЫЙ ЭТАП ЭВОЛЮЦИИ СИСТЕМЫ ВОДА - ПОРОДА - ГАЗ - ОРГАНИЧЕСКОЕ ВЕЩЕСТВО}

Появление фотосинтеза на нашей планете $\sim 2.5$ млрд лет назад внесло революционные коррективы в уже сложившийся эволюционный процесс, так как возник принципиально новый тип более сложных соединений - органических, которые многократно усложнили механизмы эволюции. Не вдаваясь в подробности механизмов фотосинтеза [Komissarov, 2003], отметим, что органическое вещество - результат химического взаимодействия воды с углекислым газом:

$$
\mathrm{H}_{2} \mathrm{O}+\mathrm{CO}_{2} \underset{\text { тепло }}{\stackrel{\text { свет }}{\longrightarrow}} \mathrm{CH}_{2} \mathrm{O}+\mathrm{O}_{2} \text {. }
$$


Реакция фотосинтеза, как и воды с алюмосиликатами, состоит тоже из двух стадий: фотолиза воды и темнового синтеза углеводов с выделением $\mathrm{O}_{2}$. Естественно, что в момент образования углеводы равновесны со средой, в которой они формируются. В противном случае они были бы разрушены этой средой. Иначе говоря, неравновесная система $\mathrm{H}_{2} \mathrm{O}$ с $\mathrm{CO}_{2}$ в определенных условиях формирует равновесный с конкретной средой вторичный продукт - простые углеводы. Среда же, которая обеспечила фотосинтез, была создана раньше системой вода - порода - газ.

Появление в результате фотосинтеза свободного кислорода привело к значительному изменению геохимической среды, в которой появились углеводы. Следовательно, разнообразная по составу вода, как продукт ее взаимодействия с алюмосиликатами, с появлением простых углеводов и $\mathrm{O}_{2}$ стала меняться еще в большей степени. Такому изменению способствовало также ее перемещение по породам и смешение с другими типами воды, в которой процессы фотосинтеза отсутствовали. Все эти изменения состава воды нарушали ее равновесие с углеводами, которые вынуждены были меняться по мере изменения водной среды. Поскольку в воде уже имелись все элементы, включая $\mathrm{H}, \mathrm{C}, \mathrm{N}, \mathrm{P}, \mathrm{O}, \mathrm{K}$, $\mathrm{S}, \mathrm{Ca}, \mathrm{Si}$ и др., растворенные молекулы углеводов получили возможность взаимодействовать с любыми компонентами такого раствора и соответственно формировать новые более сложные молекулы органических соединений, равновесные в измененных геохимических средах и поэтому устойчивые. Усложнение органических соединений проходило за счет включения в их состав растворенных в воде элементов, которые в последующем получили название биогенных [Perel'man, Kasimov, 1999], а также самой воды и отдельных составляющих ее молекул. Ведь хорошо известно, что любые живые организмы всегда содержат не менее $60 \%$ воды по весу, а в некоторых случаях ее содержание достигает 99 \% [Vernadsky, 2003]. Поскольку к моменту появления фотосинтеза на нашей планете были сформированы разные по составу типы вод, существовали все необходимые условия для образования более сложных органических соединений, устойчивых в конкретных геохимических средах.

Точно так же, как ранее естественным путем на нашей планете началось формирование вторичных минералов, появление фотосинтеза запустило новый гигантский процесс образования более сложных органических соединений, включая белки, жиры, сложные углеводы, липиды, аминокислоты, нуклеиновые кислоты, сахариды и т.д. Синтезу более сложных органических соединений способствовало то обстоятельство, что такие процессы протекали и протекают ныне в открытых стацио- нарных системах, получающих вещество и энергию из внешних сред. Такие системы всегда являются неравновесными и самоорганизующимися [Prigogine, Stengers, 1984]. В них непрерывно идут процессы синтеза новых соединений, которые равновесны с той средой, в которой они образуются. Вне термодинамического равновесия образование таких сложных соединений невозможно, поэтому в одних средах часть сформировавшихся органических соединений растворяется, но, попадая в другие условия, синтезируется в форме иных по составу и более сложных веществ, т.е. и здесь мы видим сочетание непрерывных процессов растворения и осаждения (синтеза).

Подчеркнем еще раз, что возникшая более сложная система вода - газ - органическое вещество не изолировалась от системы вода - порода, а явилась ее продолжением, поскольку источниками всех элементов, кроме $\mathrm{H}, \mathrm{O}, \mathrm{N}$ и $\mathrm{C}\left(\mathrm{H}_{2} \mathrm{O}, \mathrm{CO}_{2}\right), \mathrm{N}_{2}$, являются горные породы, а сложные органические вещества без $\mathrm{Ca}, \mathrm{P}, \mathrm{K}, \mathrm{CH}_{4}, \mathrm{Fe}, \mathrm{Si}$ и т.д. не могут формироваться.

Кроме того, система вода - органическое вещество, как и вода - алюмосиликаты, является равновесно-неравновесной. Равновесие водного раствора со многими органическими веществами мы пока рассчитать не можем, но достаточно очевидно, что все многочисленные органические соединения появляются в равновесии с тем водным раствором, который дает им жизнь и который пронизывает все клетки и межклеточное пространство растущего нового вещества. Именно вода, особенности ее состава и структуры определяют строение и состав формирующихся органических соединений, хотя более простые их аналоги были ранее растворены в такой воде, поскольку были с нею неравновесны.

Неравновесное состояние возникает и в том случае, когда какая-то часть живого организма теряет связь с функционирующей системой. Например, если лист, цветок, ветка отрывается от растения, равновесное состояние переходит в неравновесное и эти части растения гибнут, постепенно превращаясь в $\mathrm{CO}_{2}$ и $\mathrm{H}_{2} \mathrm{O}$, т.е. в компоненты, которые их создавали. Но в целом система вода - порода - газ - органическое вещество никогда полностью не гибнет, а, наоборот, непрерывно развивается и усложняется. Это происходит потому, что она функционирует на основе не случайных, а фундаментальных законов, которые лежат в основе процессов мироздания, их единства, которое определяет и создает вода. Только единство живого с неживым позволяет сохранять непрерывность действия основной функции созидания новых соединений в водном растворе, который непрерывно усложняется за счет растворения не только исходных горных пород, газов и органических веществ, 
но и вторичных соединений, создаваемых водой на предыдущих этапах.

Постепенно по мере усложнения природного водного раствора синтезируемые органические вещества становились все более и более сложными, хотя продолжали формироваться из простых соединений. Вот что по этому поводу пишут биохимики Д.Г. Кнорре и С.Д. Мызина [Knorre, Myzina, 2012]: «... белки, углеводы, нуклеиновые кислоты, липиды и другие биополимеры в растениях, у подавляющего большинства микроорганизмов, а в значительном числе случаев и у животных должны синтезироваться из простых предшественников. Как правило, такие синтезы проходят в несколько стадий и, следовательно, в живых организмах должны в тех или иных количествах присутствовать все промежуточные соединения этих биосинтетических процессов» [Knorre, Myzina, 2012, с. 59].

Действительно, все вторичные (промежуточные) соединения в природе сохраняются, поскольку по разным причинам не все они растворяются и участвуют в образовании более сложных. Нам в данном случае важно уяснить, что вторичные образования через растворение участвуют в формировании более сложных, включая различные организмы растительного и животного происхождения. Если от момента появления фотосинтеза до появления скелетных форм организмов прошло 2.0 млрд лет, что привело к резкому росту биоразнообразия, то от скелетных форм до появления человека всего 0.5 млрд лет. Но исходные системы, включая базальты, не исчезли, хотя и покрылись разнообразными вторичными продуктами.

Если возьмем, например, растения со своими частями, каждая из которых наделена особыми функциями, то убедимся в тесной их связи с системой вода - порода. Так, корни растений, питаясь подземной водой, состав которой определен стадией ее взаимодействия с горными породами, обеспечивают доставку растворенных химических элементов и самих растворов в места, где формируются разные части растения - листья, сучья, кора, цветы, плоды и т.д. Эти процессы протекают в условиях равновесно-неравновесного состояния системы вода-органическое вещество, которая сама развивается в области, далекой от равновесия. Таким образом обеспечивается непрерывный синтез в водном растворе в условиях равновесия более сложных органических соединений, которые без воды определенного состава не смогли бы возникнуть. Растения получают солнечную энергию в процессе фотосинтеза, а питательные вещества из воды, которая, в свою очередь, берет их из горных пород. Так организуется взаимодействие всех основных компонентов окружающего мира - воды, породы, газов и органических соединений. Но и здесь вода остается главным фактором внутренней эволюции, так как она контролирует состав образующихся соединений, характер среды, энергетическое состояние системы, направленность эволюции и т.д.

Необходимо учитывать также, что со временем растет не только сложность системы, но и ее упорядоченность, присущая при определенных условиях химическим соединениям углерода - основного элемента органических образований.

Животные, в отличие от растений, питаются не только водой, но и растительной и мясной пищей, которая неравновесна со средой живого организма и не может усваиваться без предварительной подготовки. Только в растворенном состоянии ионы и молекулы поступают непосредственно в организм, у теплокровных животных - в кровь. В конечном счете, любой живой организм непрерывно получает пищу только в растворенном виде.

Следовательно, живой организм можно представить в форме сложного сосуда, стенки которого, с одной стороны, изолируют его содержимое от прямого воздействия внешней среды, а с другой обеспечивают возможность получения из среды вещества и энергии. Но поступающее в живой организм вещество из внешней среды неравновесно с той средой, которая имеет место в организме. Взаимодействие чужеродного для организма вещества происходит в неравновесных условиях, поскольку жизнь в равновесных условиях невозможна [Krylov, 2017]. Именно в неравновесных условиях происходит переваривание (растворение) пищи. И только те компоненты, которые перешли в раствор, попадают непосредственно в систему (кровь), где совершается синтез новых соединений.

Синтез соединений в любом организме идет непрерывно, трудно найти какой-либо орган, где этот процесс отсутствует. Чрезвычайно важно то, что образование новых соединений происходит в определенных местах, точках нуклеации, в которых достигается равновесие, а значит, и устойчивость образующихся веществ, определяемая стабильностью всей системы, одинаковыми путями переноса вещества и средой. Следовательно, для живых организмов, как и для системы вода - порода, характерно равновесно-неравновесное состояние. Живые системы являются стационарными, необратимыми, развиваются в неравновесных условиях. Химические элементы, попадающие в кровь, - сложнейшее жидкое соединение, которое получает возможность взаимодействовать с элементами из разной пищи и воздуха, а значит, и формировать новые более сложные органические вещества, которые, в свою очередь, образуют органы животного (печень, почки, кости и т.д.). Но синтез этих сложных соединений происходит в условиях равновесия 
Т а б л и ц а 2. Содержание воды в органах человека и среднее значение диэлектрической проницаемости тканей $\left(\varepsilon_{s}\right)$ [Rassadkin, 2008]

$\mathrm{T}$ a b l e 2. Water content in human organs, and an average dielectric inductivity of tissues ( $\left.\mathcal{E}_{\mathrm{s}}\right)$ [Rassadkin, 2008]

\begin{tabular}{|c|c|c|c|c|c|c|c|c|c|c|c|c|}
\hline Орган & Мозг & Печень & Почки & Селезенка & Легкие & Сердце & Кожа & Глаза & Мышцы & Кровь & Жир & Кости \\
\hline Вода, \% & 75 & 68 & 83 & 76 & 79 & 79 & 72 & 80 & 75 & 83 & 10 & 22 \\
\hline$\varepsilon_{\mathrm{s}}$ & 35 & 44 & 50 & 77 & 35 & 50 & 44 & 70 & 50 & 65 & 3.0 & 8.4 \\
\hline
\end{tabular}

с конкретной биохимической средой. Именно равновесие со средой (кровью) делает возникающие зародыши новых веществ исключительно устойчивыми, способными к длительному росту, сохранению и стабильности. Рост зародышей обеспечивается непрерывным поступлением в систему питательных веществ из желудочно-кишечного тракта, который, в свою очередь, получает их из внешней среды. Разнообразие же зародышей определяется наличием разных сред даже в весьма ограниченном пространстве.

Об изменении среды в органах живых организмов мы можем судить, например, по содержанию $\mathrm{H}_{2} \mathrm{O}$ и значениям ее диэлектрической проницаемости $\left(\mathcal{E}_{\mathrm{s}}\right)$ в различных органах человека (табл. 2). Как видно из приведенных данных, органы человека, расположенные рядом друг с другом, резко отличаются по этим параметрам. При этом с изменением количества воды изменяется ее проницаемость, а значит, и другие свойства, т.е. биохимическая среда в целом.

Следовательно, некоторые общие принципы эволюции системы вода - органическое вещество в живых организмах одинаковы с системой вода - порода. Все это говорит об унаследовании механизмов эволюции живой материей от «косной». Связующим звеном живого и «косного» выступает вода, которая благодаря своим уникальным свойствам обеспечила непрерывный переход эволюции из мертвой материи в живую. Но такой переход - это не механическая передача функций от материнской системы к дочерней, а глубокое усложнение состава и структуры воды. На каждом новом этапе эволюции фактически появлялась иная вода. Если принять во внимание идеи В.И. Вернадского [Vernadsky, 2003] о том, что вода - это не один минерал, а множество, то каждый этап эволюции формирует свой водный минерал, который отличается от других составом и структурой. И каждый новый минерал воды оказывается сложнее его предшественника.

Особенно четко различие состава воды можно увидеть, если сравнить первые стадии ее взаимодействия с алюмосиликатами в коре выветривания, где формируются в основном пресные воды $\mathrm{HCO}_{3}-\mathrm{Na}$ типа с соленостью <1 г/л [Shvartsev, 1998], с рассолами последних стадий в осадочных бас- сейнах платформ, соленость которых достигает 600 г/л, а состав представлен Cl-Ca солями с содержанием граммовых количеств $\mathrm{Ca}, \mathrm{Mg}, \mathrm{Cl}, \mathrm{Br}, \mathrm{Sr}$, $\mathrm{Li}$ и многих других элементов [Pinneker, 1966; Krainov et al., 2012].

Совсем другое направление эволюции состава природных вод характерно для системы вода - органическое вещество - газы. Теплокровные животные и человек пьют воду преимущественно речную, озерную или подземную с соленостью <1 г/л (животные - иногда до 5 г/л) с небольшим содержанием простых органических соединений. Но за длинную историю эволюции (>2.0 млрд лет) усложнение состава воды оказалось настолько сильным, что такую воду стали называть кровью, которая отличается, прежде всего, большим количеством в ней сложных и разнообразных органических соединений.

Основа крови - это вода (77-82 \%) и органоминеральный сухой остаток (18-23\%), в котором доля минеральных веществ составляет только 1.2$1.6 \%$, а органических - 16.8-23.4\%, т.е. кровь - это вода, в которой резко доминируют не минеральные, а органические соединения. Кровь - неоднородная жидкость: она состоит из плазмы (54-59 \%) и эритроцитов (41-46\%). В составе первой 9091 \%, а вторых - 57-68 \% воды. Плазма и эритроциты отличаются также по плотности: 1.02-1.03 и

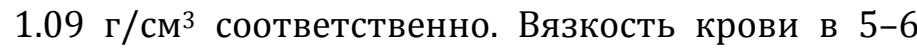
раз выше вязкости воды, рН колеблется в очень узких пределах - от 7.35 до 7.42.

В плазме доминируют белки, 6.5-8.5 \% из 9-10 \% сухого остатка, в эритроцитах - гемоглобин, 3041 \% из 32-43 \% сухого остатка. Белковые фракции плазмы неоднородны: в них обнаружено около 100 видов белковых компонентов, среди которых резко доминируют альбумины (55-60 \% всех белков), глобулины (27-36 \%) и фибриноген (2.7-5.5 \%). В меньшем количестве в крови содержатся углеводы, которые представлены главным образом глюкозой и продуктами ее превращения (0.8-1.2 г/л), а также липиды (4.0-7.2 г/л), смесь которых состоит в основном из нейтральных жиров, жирных кислот, свободного и связанного холестерина и т.д. Ионы $\mathrm{HCO}_{3}{ }^{-}$и растворенная $\mathrm{H}_{2} \mathrm{CO}_{3}$ образуют бикарбонатную, а ионы $\mathrm{HPO}_{4}{ }^{2-}-$ фосфатную буферные си- 
стемы. Кровь богата и различными микроэлементами, играющими важную биохимическую роль [Berezov, Korovkin, 1998].

Таким образом, с появлением фотосинтеза направленность созидательной функции воды резко изменилась. Если до фотосинтеза вода формировала вторичные минеральные продукты (осадочные, гидротермально измененные и метаморфические породы и руды вплоть до гранитогнейсов и гранитов [Shvartsev, 2016]), то с появлением фотосинтеза началось формирование растительности, а значит, и торфа, угля, нефти, метанового газа, а также белков, углеводов и липидов, а затем и живых организмов (животных и человека). Именно изменение состава воды в равновесно-неравновесных, открытых, нелинейных и необратимых условиях взаимодействия с непрерывно усложняющимися минеральными и органическими соединениями обеспечило развитие эволюции в принципиально новом направлении.

Все сказанное показывает, что вода в биологических системах не просто транспортирует питательные вещества, регулирует температуру тела, выводит из организма отходы, вымывает токсины, смазывает соединения суставов, как это принято считать, а создает организм в целом, определяет его свойства, форму, структуру, функции, механизмы действия, направленность эволюции. Вода входит составной частью во все органы живого организма и в зависимости от размера сосудов меняет свои свойства [Rassadkin, 2008]. Это обстоятельство определяет, по нашему мнению, протекание всех обменных процессов в живом организме.

Итак, во всех главных системах (царствах) нашей планеты - минеральной, растительной и животной, включая человека, - действуют одни и те же принципы эволюции, обусловленные одними причинами и механизмами. Основным созидательным и связующим компонентом этих систем является вода, которая буквально пронизывает все их составляющие. В условиях внутренне противоречивого равновесно-неравновесного состояния вода непрерывно растворяет по механизму гидролиза любые образования (минеральные, органические, органоминеральные и др.), с которыми она неравновесна, но одновременно создает принципиально новые образования, включая и ранее неизвестные на Земле. При этом если среда в той или иной системе геологически долго остается стабильной, одинаковые вторичные продукты будут формироваться в течение долгого времени.

Но вода обладает еще одним важнейшим свойством - она всегда участвует в тех или иных круговоротах, поэтому образовавшиеся вторичные продукты через какое-то время оказываются в воде иного состава, с которой они неравновесны. Эта новая вода частично растворяет вторичные продукты и изменяет свой состав. Если же эта химически измененная вода далее попадает в материнские образования, с которыми она неравновесна, то будет формировать иные, отличающиеся от предыдущих вторичные образования.

Этот момент в эволюции взаимодействия воды с «косным» или живым веществом принципиально важен, поскольку раскрывает еще один механизм усложнения как результат эволюции системы вода - порода - газ - органическое вещество, которую мы предложили называть системой В.И. Вернадского [Alekseev et al., 2005]. В общем виде этот механизм заключается в том, что спустя некоторое время после появления воды на планете и начала ее взаимодействия с базальтами на дневной поверхности образовались продукты выветривания. Более поздние порции воды, поступающей на поверхность Земли, в первую очередь взаимодействуют с этими вторичными образованиями, растворяя их и изменяя свой состав. Такая измененная вода, достигая поверхности базальтов на некоторой глубине, формирует вторичные минералы не первой, а более поздних стадий [Shvartsev, 2001, 2008a, 2009, 2010, 2016; Shvartsev et al., 2007]. После появления фотосинтеза к вторичным минеральным образованиям добавились органические и органо-минеральные, что обеспечило дальнейшее непрерывное усложнение системы.

Так, современная дождевая вода, прежде чем попасть в организм человека, проходит через крону деревьев, разные почвенные горизонты, разнообразные коры выветривания, взаимодействует с различными осадочными, реже магматическими или метаморфическими породами. Затем она оказывается в реке или озере, где процветают различные формы жизни, протекают разнообразные химико-биологические процессы, развиваются многочисленные бактерии. Вот такой, а также пресной подземной водой, которая обогащена практически всеми химическими элементами и их минеральноорганическими соединениями, питаются растения, животные, человек, т.е. все живое на планете. Кроме того, животные и человек употребляют в пищу многие вторичные продукты (мясо, растения, овощи, фрукты, ягоды, молоко и т.д.), которые всегда содержат не менее 60 \% воды, еще более разнообразной по составу и структуре, богатой различными сложными органическими соединениями. С этой пищей человек получает сложные органические и органо-минеральные соединения, включая разнообразные белки, углеводы, липиды и т.д. В результате процесса растворения и осаждения в течение всей геологической истории при многоэтапных превращениях в водном растворе минеральных, а позже и органических соединений воз- 


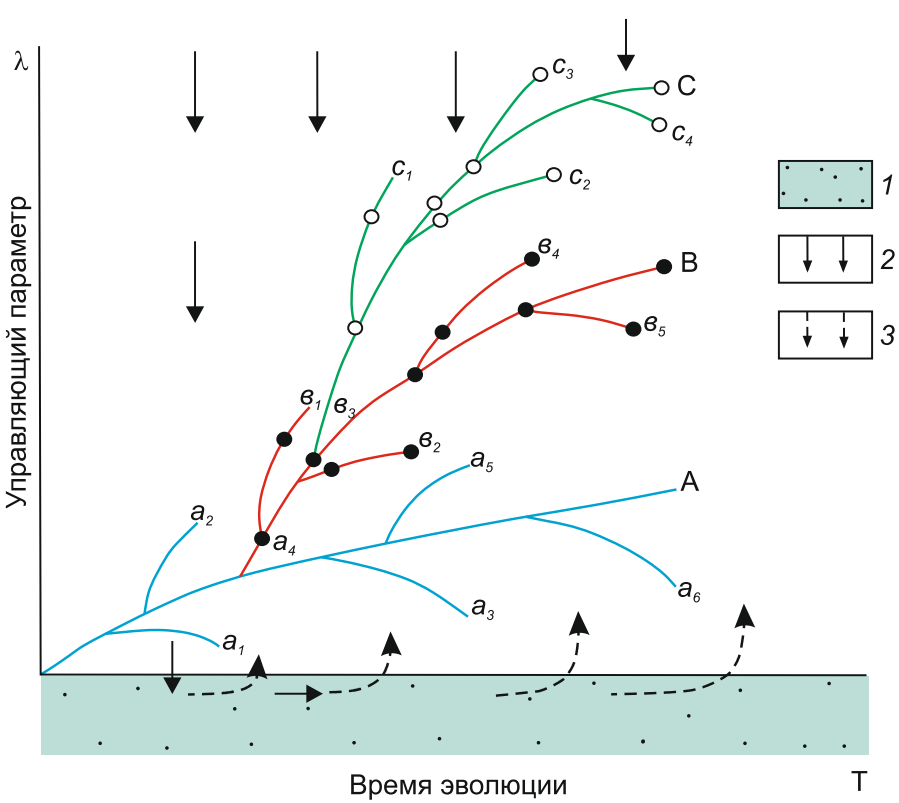

ник современный исключительно сложный окружающий мир.

В самом общем виде мы можем выделить три основных этапа усложнения этого вторичного мира в процессе глобальной эволюции на нашей планете. На первом этапе усложнение происходит за счет преобразования водой исходных на Земле горных пород - базальтов (рисунок, ветвь А). На втором добавляется взаимодействие с органическим веществом - продуктом фотосинтеза, который начинается в геохимических средах, сформированных на первом этапе (ветвь В), но постепенно меняющихся из геохимических на биогеохимические. На третьем этапе усложнение связано в основном с преобразованием (перевариванием) вторичных минеральных и органических образований, попадающих в организм животного и человека, т.е. пищи (ветвь С). Каждый этап эволюции протекает в ином, более сложном, водном растворе, который непрерывно усложняется за счет растворения новых более сложных вторичных образований. Принципиально важно то, что усложнение происходит одновременно водного раствора и всех вторичных образований [Shvartsev, 2014].

Все эти преобразования стали возможны благодаря наличию в системе вода - эндогенные породы внутренней эволюции, которая позже унаследована системой вода - органическое вещество, а еще позже - вода - живые организмы. Внутренняя эволюция в системе вода - порода - газ - органическое вещество, начавшаяся еще до появления живых организмов, является прямым доказательством отсутствия какой-либо ее связи с идеей «власти жизни». Эту функцию - функцию созидательной силы выполняет вода [Shvartsev, 2008a, 2012].
Схема последовательного усложнения состава водного раствора в ходе глобальной эволюции.

Термодинамические ветви системы: А - вода - порода; В вода - растения; С - вода - животные; дочерние системы: $\mathrm{a}_{1-}$ $\mathrm{a}_{n}$ - ветви A; $8_{1}-B_{n}-$ ветви B; $\mathrm{c}_{1}-\mathrm{C}_{n}-$ ветви С. 1 - исходная горная порода; 2 - вода, поступающая из внешнего источника; 3 - вода после взаимодействия с горными породами и органическим веществом.

Gradual complication of the aqueous solution composition in the course of the global evolution.

Thermodynamic branches of the system: A - water - rock; B water - flora; C - water - fauna; daughter systems: $\mathrm{a}_{1}-\mathrm{a}_{n}-$ branches A; $B_{1}-B_{n}$ - branches $B$; $c_{1}-c_{n}$ - branches C. 1 - source rock; 2 - water from an external source; 3 - water after interaction with rocks and organic matter.

\section{4. ЗАКЛЮЧЕНИЕ}

С момента появления воды на Земле возникла стационарная неравновесно-равновесная система вода - порода, обладающая внутренне противоречивым характером, который обеспечивает ее самопроизвольное, непрерывное, геологически длительное развитие с образованием принципиально новых минеральных фаз и геохимических типов воды. Эта система в пределах земной коры (при $\mathrm{T}<400{ }^{\circ} \mathrm{C}$ ) развивается постоянно в нелинейной области термодинамической ветви в условиях, далеких от равновесия, и относится к типу абиогенных диссипативных, играющих особую роль в прогрессивном развитии «косной» материи.

Способность этой системы непрерывно растворять одни минералы и практически одновременно формировать новые, отличающиеся по составу и структуре от исходных растворяемых, обеспечила формирование последовательно сменяющихся гидрогенно-минеральных комплексов, состоящих из разных парагенетически связанных геохимических типов воды и вторичных минеральных образований, представленных разнообразными продуктами выветривания, осадочной седиментации пород разной степени диа- и катагенеза, низкотемпературного метаморфизма, гальмиролиза и т.д. Важно, что все эти вторичные комплексы непрерывно усложняются по составу и структуре, что обеспечило эволюцию в неживой материи.

Появление фотосинтеза, обеспечившее образование органических соединений, не только многократно усложнило рассматриваемую систему и многие механизмы взаимодействия ее компонентов, но и направило эволюцию этой системы в но- 
вое русло. В результате из простых органических соединений возникли более сложные, включая белки, углеводы, липиды и др. За счет растворенных органических соединений коренным образом изменился состав воды, а среда из чисто химической трансформировалась в биогеохимическую, что в итоге и привело к появлению живых организмов.

Вследствие постоянного круговорота воды вторичные минеральные и органические образования непрерывно подвергаются частичному растворению ее новыми порциями. В результате этого состав водного раствора изменяется еще до попадания в исходные (материнские) породы. Это обстоятельство привело как минимум к двум дополнительным механизмам усложнения системы: 1) состав воды изменяется еще до взаимодействия с первичными породами и базовыми органическими соединениями, что обеспечивает дополнительное усложнение системы в целом; 2) смешение разных типов водных растворов, измененных за счет растворения вторичных и первичных минералов, а также различных органических веществ, привело к еще большему эффекту усложнения системы.

Возникновение жизни обеспечило появление нового грандиозного этапа усложнения системы В.И. Вернадского вода - порода - газ - органическое вещество (мертвое и живое). Постепенное, но непрерывное усложнение водного раствора органическими соединениями привело к появлению принципиально нового типа воды - крови, которая обеспечила формирование наиболее сложных живых организмов, включая человека.

Несмотря на тысячекратное усложнение механизмов взаимодействия ведущих компонентов системы В.И. Вернадского, основные принципы эволюции, заложенные в системе вода - порода на ранних стадиях развития планеты, в своей основе сохранились. Система осталась открытой, равновесно-неравновесной, внутренне противоречивой, нелинейной, необратимой, развивающейся в области, далекой от равновесия, а вода сохранила способность за счет растворения одних соединений создавать более сложные.

Эволюция рассматриваемой системы - результат наличия внутренних механизмов непрерывного взаимодействия всех ее компонентов, обусловленного несовместимостью состава и структуры воды на первых этапах эволюции с базальтами, а позже и с другими образованиями, которые она растворяет. Превращение одного твердого соединения в результате растворения и осаждения в другое - главный механизм эволюции, который непрерывно разрушает один существующий мир и создает новый, ранее неизвестный. В этом и заключается основная созидательная функция воды в окружающем нас мире.

Вода, связываемая в процессе гидролиза вторичными «косными» продуктами и живыми организмами, аккумулирует солнечную энергию и тем самым переходит на более высокий энергетический уровень, что обеспечивает уменьшение энтропии, а значит, является основой становления упорядоченности, причиной усложнения системы в целом. Такая эволюция служит базой перехода от хаоса к порядку, новому структурогенезу, движущей силой, обеспечивающей изменение необратимых потоков энергии, приводящих к новой рациональности устройства окружающего мира.

\section{5. БЛАГОДАРНОСТИ}

Работа выполнена при финансовой поддержке РНФ (проект № 17-17-01158).

\section{6. ЛИТЕРАTУРA / REFERENCES}

Aagaard P., Helgeson H.C., 1982. Thermodynamic and kinetic constraints on reaction rates among minerals and aqueous solutions. I. Theoretical considerations. American Journal of Science 282 (3), 237-285. https://doi.org/ 10.2475/ajs.282.3.237.

Alekseev V.A., 2002. Kinetics and Mechanisms of Reactions Between Feldspar and Aqueous Solutions. GEOS, Moscow, 256 p. (in Russian) [Алексеев B.A. Кинетика и механизмы реакций полевых шпатов с водными растворами. M.: ГEOC, 2002, 256 c.]

Alekseev V.A., Ryzhenko B.N., Shvartsev S.L., Zverev V.P., Bukaty M.B., Mironenko M.V., Charykova M.V., Chudayev O.V., 2005. Geological Evolution and Self-Organization of the Water-Rock System. Vol. 1. The Water-Rock System in the Earth's Crust: Interaction, Kinetics, Equilibrium, and Modeling. Publishing House of SB RAS, Novosibirsk, 244 p. (in Russian) [Алексеев В.А., Рыженко Б.Н., Швариев С.Л., Зверев В.П., Букаты М.Б., Мироненко М.В., Чарыкова М.В., Чудаев O.B. Геологическая эволюция и самоорганизация системы вода - порода. Т. 1. Система вода - порода в земной коре: взаимодействие, кинетика, равновесие, моделирование. Новосибирск: Изд-во СО РАН, 2005. 244 c.].

Alekseyev V.A., Medvedeva L.S., Prisyagina N.I., Meshalkin S.S., Balabin A.I., 1997. Change in the dissolution rates of alkali feldspars as a result of secondary mineral precipitation and approach to equilibrium. Geochimica et Cosmochimica Acta 61 (6), 1125-1142. https://doi.org/10.1016/S0016-7037(96)00405-X. 
Berezov T.T., Korovkin B.F., 1998. Biological Chemistry. ${ }^{\text {rd }}$ Edition. Meditsina (Medicine), Moscow, 704 p. (in Russian) [Березов Т.T., Коровкин Б.Ф. Биологическая химия. Издание 3-е. М.: Медицина, 1998. 704 с.].

Correns C.W., 1961. The experimental chemical weathering of silicates. Clay Minerals Bulletin 4 (26), 249-265. https://doi.org/10.1180/claymin.1961.004.26.01.

Dawkins R., 2012. The Greatest Show on Earth: The Evidence for Evolution. Corpus, Moscow, 496 p. (in Russian) [Докинз P. Самое грандиозное шоу на Земле. Доказательства эволюции. М.: Corpus, 2012. 496 с.].

Fin'ko V.I., Chekin S.S., Samatoin N.D., 1980. Features of kaolinization of rock-forming silicates in weathering crusts. In: V.I. Smirnov (Ed.), Problems of the theory of formation of weathering crust, and exogenous deposits. Nauka, Moscow, p. 196-201 (in Russian) [Финько В.И., Чекин С.С., Саматоин Н.Д. Особенности каолинизации породообразующих силикатов в корах выветривания // Проблемы теории образования коры выветривания и экзогенные месторождения / Ред. В.И. Смирнов. М.: Наука, 1980. С. 196-201].

Fu Q., Lu P., Konishi H., Dilmore R., Xu H., Seyfried Jr. W.E., Zhu C., 2009. Coupled alkali-feldspar dissolution and secondary mineral precipitation in batch systems: 1 . New experiments at $200{ }^{\circ} \mathrm{C}$ and 300 bars. Chemical Geology 258 (3-4), 125-135. https://doi.org/10.1016/j.chemgeo.2008.09.014.

Garrels R.M., Christ C.L., 1965. Solutions, Minerals and Equilibria. Harper \& Row, New York, 450 р. [Русский перевод: Гаррелс Р.М., Крайст Ч.Л. Растворы, минералы, равновесия. М.: Мир, 1968. 368 с.].

Garrels R.M., MacKenzie F.T., 1967. Origin of the chemical compositions of some springs and lakes. In: R.F. Gould (Ed.), Equillibrium concepts in natural waters systems. Advances in Chemistry, vol. 67, p. 222-242. https://doi.org/ 10.1021/ba-1967-0067.ch010.

Harlov D.E., Wirth R., Hetherington C.J., 2011. Fluid-mediated partial alteration in monazite: the role of coupled dissolution-reprecipitation in element redistribution and mass transfer. Contributions to Mineralogy and Petrology 162 (2), 329-348. https://doi.org/10.1007/s00410-010-0599-7.

Helgeson H.C., 1968. Evaluation of irreversible reactions in geochemical processes involving minerals and aqueous solutions - I. Thermodynamic relations. Geochimica et Cosmochimica Acta 32 (8), 853-877. https://doi.org/ 10.1016/0016-7037(68)90100-2.

Helgeson H.C., Garrels R.M., MacKenzie F.T., 1969. Evaluation of irreversible reactions in geochemical processes involving minerals and aqueous solutions - II. Applications. Geochimica et Cosmochimica Acta 33 (4), 455-481. https://doi.org/10.1016/0016-7037(69)90127-6.

Helgeson H.C., Murphy W.M., 1983. Calculation of mass transfer among minerals and aqueous solutions as a function of time and surface area in geochemical processes. I. Computational approach. Journal of the International Association for Mathematical Geology 15 (1), 109-130. https://doi.org/10.1007/BF01030078.

Helgeson H.C., Murphy W.M., Aagaard P., 1984. Thermodynamic and kinetic constraints on reaction rates among minerals and aqueous solutions. II. Rate constants, effective surface area, and the hydrolysis of feldspar. Geochimica et Cosmochimica Acta 48 (12), 2405-2432. https://doi.org/10.1016/0016-7037(84)90294-1.

Hellmann R., Penisson J.M., Hervig R.L., Thomassin J.H., Abrioux M.F., 2003. An EFTEM/HRTEM high-resolution study of the near surface of labradorite feldspar altered at acid $\mathrm{pH}$ : evidence for interfacial dissolution-reprecipitation. Physics and Chemistry of Minerals 30 (4), 192-197. https://doi.org/10.1007/s00269-003-0308-4.

Keller W.D., 1963. Basics of chemical weathering. In: A.B. Ronov (Ed.), Geochemistry of Lithogenesis. Inostrannaya Literatura (Foreign Literature), Moscow, p. 85-195 (in Russian) [Келлер У.Д. Основы химического выветривания // Геохимия литогенеза / Ред. А.Б. Ронов. М.: Иностранная литература, 1963. С. 85-195].

Khaitun S.D., 2009. The Phenomenon of Man at the Background of Universal Evolution. Komkniga, Moscow, 536 p. (in Russian) [Хайтун С.Д. Феномен человека на фоне универсальной эволюции. М.: Комкнига, 2009. 536 с.]

Knorre D.G., Myzina S.D., 2012. Biological Chemistry (4th Edition). Publishing House of the SB RAS, Novosibirsk, 456 p. (in Russian) [Кнорре Д.Г., Мызина С.Д. Биологическая химия. Издание 4-е. Новосибирск: Изд-во СО РАН, 2012. 456 c.].

Knyazeva E.N., Kurdyumov S.P., 2005. Foundations of Synergetics. Synergistic World Vision. KomKniga, Moscow, 240 p. (in Russian) [Князева E.Н., Курдюмов С.П. Основания синергетики. Синергетическое мировидение. М.: КомКнига, 2005. 240 с.].

Komissarov G.G., 2003. Photosynthesis: physicochemical approach. Chemical Physics 22 (1), 24-54 (in Russian) [Koмиссаров Г.Г. Фотосинтез: физико-химический подход // Химическая физика. 2003. Т. 22. № 1. С. 24-54].

Krainov S.R., Ryzhenko B.N., Shvets V.M., 2012. Geochemistry of Groundwater. CentrLitNeftegaz, Moscow, 672 p. (in Russian) [Крайнов С.Р., Рыженко Б.Н., Швец В.М. Геохимия подземных вод. М.: ЦентрЛитНефтегаз, 2012. 672 c.].

Krylov M.V., 2017. Evolutionary commonality of nonliving nature and living organisms. Herald of the Russian Academy of Sciences 87 (3), 249-255. https://doi.org/10.1134/S1019331617030029.

Kunin E.V., 2014. The Logic of the Case: On the Nature and Origin of Biological Evolution. Centrpoligraf, Moscow, 760 p. (in Russian) [Кунин E.B. Логика случая: О природе и происхождении биологической эволюции. М.: Центрполиграф, 2014. 760 с.].

Lu P., Konishi H., Oelkers E., Zhu C., 2015. Coupled alkali feldspar dissolution and secondary mineral precipitation in batch systems: 5. Results of K-feldspar hydrolysis experiments. Chinese Journal of Geochemistry 34 (1), 1-12. https://doi.org/10.1007/s11631-014-0029-z. 
Millot G., 1964. Géologie des Argiles. Masson, Paris, 499 p.

Moiseev N.N., 1998. Parting with Simplicity. AGRAF, Moscow, 473 p. (in Russian) [Моисеев Н.Н. Расставание с простотой. М.: АГРАФ, 1998. 473 с.].

Nicolis G., Prigogine I., 1989. Exploring Complexity: An Introduction. W.H. Freeman and Company, New York, 328 p. [Русский перевод: Николис Г., Пригожин И. Познание сложного. Введение. М.: ЛКИ, 2008. 352 с.].

O'Neil J.R., Taylor Jr. H.P., 1967. The oxygen isotope and cation exchange chemistry of feldspars. American Mineralogist 52 (9-10), 1414-1437.

Paquet H., 1970. Evolution Géochimique des Minéraux Argileux Dans les Altérations et les Sols des Climats Méditerranéens Tropicaux (Saisons Contrastées). Strasbourg, 212 p.

Pedro G., 1964. Contribution à l'Étude Expérimentale de l'Altération Géochimique des Roches Cristallines. Paris, 223 p.

Perel'man A.I., Kasimov N.S., 1999. Geochemistry of the Landscape. Astreya-2000, Moscow, 768 p. (in Russian) [Пeрельман А.И., Касимов Н.С. Геохимия ландшафта. М.: Астрея-2000, 1999. 768 с.].

Pinneker E.V., 1966. Brines of Angara-Lena Basin. Nauka, Moscow, 332 p. (in Russian) [Пиннекер Е.В. Рассолы Ангаро-Ленского бассейна. М.: Наука, 1966. 332 с.].

Plyusnin A.M., Zamana L.V., Shvartsev S.L., Tokarenko O.G., Chernyavskii M.K., 2013. Hydrogeochemical peculiarities of the composition of nitric thermal waters in the Baikal Rift zone. Russian Geology and Geophysics 54 (5), 495-508. https://doi.org/10.1016/j.rgg.2013.04.002.

Polynov B.B., 1956. Selected Works. Publishing House of the USSR Acad. Sci., Moscow, 751 p. (in Russian) [Полынов Б.Б. Избранные труды. М.: Изд-во АН СССР, 1956. 751 с.].

Prigogine I., Stengers I., 1984. Order Out of Chaos. Man's New Dialogue with Nature. Bantam Books, New York, 385 p [Русский перевод: Пригожин И., Стенгерс И. Порядок из хаоса. Новый диалог человека с природой. Издание 4-е. М.: Едиториал УРСС, 2003. 312 с.].

Putnis A., 2002. Mineral replacement reactions: from macroscopic observations to microscopic mechanisms. Mineralogical Magazine 66 (5), 689-708.

Rassadkin Yu.P., 2008. Water, Ordinary and Extraordinary. STO Gallery, Moscow, 840 p. (in Russian) [Рассадкин Ю.П. Вода обыкновенная и необыкновенная. М.: Галерея СТО, 2008. 840 с.].

Schrödinger E., 1972. What is Life? Atomizdat, Moscow, 90 p. (in Russian) [Шрёдингер Э. Что такое жизнь? М.: Атомиздат, 1972. 90 с.].

Sedletsky I.D., 1937. Genesis of minerals of soil colloids of the montmorillonite group. Doklady AN SSSR 17 (7), 371-373 (in Russian) [Седлецкий И.Д. Генезис минералов почвенных коллоидов группы монтмориллонита // Доклады АН СССР. 1937. Т. 17. № 7. С. 371-373].

Shvartsev S.L., 1972. The chemical composition of groundwater in tropical countries (Guinea). Geokhimiya (Geochemistry) (1), 100-109 (in Russian) [Шварцев С.Л. Химический состав грунтовых вод тропических стран (на примере Гвинеи) // Геохимия. 1972. № 1. С. 100-109].

Shvartsev S.L., 1976. Laterite of Guinea and the geochemical conditions of their formation. In: D.G. Sapozhnikov (Ed.), Weathering crust. Issue 15. Nauka, Moscow, p. 51-70 (in Russian) [Шварцев С.Л. Латериты Гвинеи и геохимические условия их образования // Кора выветривания. Вып. 15 / Ред. Д.Г. Сапожников. М.: Наука, 1976. C. 51-70].

Shvartsev S.L., 1978. Hydrogeochemistry of the Zone of Hypergenesis. Nedra, Moscow, 288 p. (in Russian) [Шварцев С.Л. Гидрогеохимия зоны гипергенеза. М.: Недра, 1978. 288 с.].

Shvartsev S.L., 1991. The interaction of water and aluminosilicate rocks. Overview. Geologiya i Geofizika (Soviet Geology and Geophysics) 32 (12), 16-50 (in Russian) [Шварцев С.Л. Взаимодействие воды с алюмосиликатными горными породами. Обзор // Геология и геофизика. 1991. Т. 32. № 12. С. 16-50].

Shvartsev S.L., 1998. Hydrogeochemistry of the Zone of Hypergenesis. $2^{\text {nd }}$ Edition. Nedra, Moscow, 367 p. (in Russian) [Шварцев С.Л. Гидрогеохимия зоны гипергенеза. Издание 2-е. М.: Недра, 1998. 367 с.]

Shvartsev S.L., 2001. The water-rock system synergy. Earth Science Frontiers 8 (1), 36-46.

Shvartsev S.L., 2003. Bound water as an accumulator of solar energy in supergene clays. Geologiya i Geofizika (Russian Geology and Geophysics) 44 (3), 233-239.

Shvartsev S.L., 2007. Progressively self-organizing abiogenic dissipative structures in the Earth's geologic history. Litosfera (Lithosphere) (1), 65-89 (in Russian) [Шварцев С.Л. Прогрессивно самоорганизующиеся абиогенные диссипативные структуры в геологической истории Земли // Литосфера. 2007. № 1. С. 65-89].

Shvartsev S.L., 2008a. Fundamental mechanisms of interaction in the water-rock system and its interior geological evolution. Litosfera (Lithosphere) (6), 3-24 (in Russian) [Шварцев С.Л. Фундаментальные механизмы взаимодействия в системе вода - горная порода и ее внутренняя геологическая эволюция // Литосфера. 2008. № 6. C. 3-24].

Shvartsev S.L., 2008b. Geochemistry of fresh groundwater in the main landscape zones of the Earth. Geochemistry International 46 (13), 1285-1398. https://doi.org/10.1134/S0016702908130016.

Shvartsev S.L., 2009. Self-organizing abiogenic dissipative structures in the geologic history of the Earth. Earth Science Frontiers 16 (6), 257-275. https://doi.org/10.1016/S1872-5791(08)60114-1. 
Shvartsev S.L., 2010. Where did global evolution begin? Herald of the Russian Academy of Sciences 80 (2), 173-182. https://doi.org/10.1134/S1019331610020097.

Shvartsev S.L., 2012. The internal evolution of the water-rock geological system. Herald of the Russian Academy of Sciences 82 (2), 134-142. https://doi.org/10.1134/S1019331612020049.

Shvartsev S.L., 2013a. Two hundred and ten years of hydrogeology. Geoekologiya (Geoecology) (3), 272-279 (in Russian) [Шварцев С.Л. Двести десять лет гидрогеологии // Геоэкология. 2013. № 3. С. 272-279].

Shvartsev S.L., 2013b. Water as the main factor of global evolution. Herald of the Russian Academy of Sciences 83 (1), 78-85. https://doi.org/10.1134/S1019331613010139.

Shvartsev S.L., 2014. How do complexities form? Herald of the Russian Academy of Sciences 84 (4), 300-309. https://doi.org/10.1134/S1019331614040029.

Shvartsev S.L., 2015. The basic contradiction that predetermined the mechanisms and vector of global evolution. Herald of the Russian Academy of Sciences 85 (4), 342-351. https://doi.org/10.1134/S101933161503003X.

Shvartsev S.L., 2016. Unknown mechanisms of granitization of basalts. Herald of the Russian Academy of Sciences 86 (6), 513-526. https://doi.org/10.1134/S1019331616060149.

Shvartsev S.L., 2017a. Do additive technologies have a future? Herald of the Russian Academy of Sciences 87 (3), 267-275. https://doi.org/10.1134/S101933161703008X.

Shvartsev S.L., 2017b. Evolution in nonliving matter: Nature, mechanisms, complication, and self-organization. Herald of the Russian Academy of Sciences 87 (6), 518-526. https://doi.org/10.1134/S1019331617050069.

Shvartsev S.L., Kharitonova N.A., Lepokurova O.E., Chelnokov G.A., 2017. Genesis and evolution of high-pCO 2 groundwaters of the Mukhen spa (Russian Far East). Russian Geology and Geophysics 58 (1), 37-46. https://doi.org/ 10.1016/j.rgg.2016.12.002.

Shvartsev S.L., Ryzhenko B.N., Alekseev V.A., Dutova E.M., Kondratieva I.A., Kopylova Yu.G., Lepokurova O.E., 2007. Geological Evolution and Self-Organization of the Water-Rock System. Vol. 2. The Water-Rock System in Conditions of the Zone of Hypergenesis. Publishing House of SB RAS, Novosibirsk, 389 p. (in Russian) [Шварцев С.Л., Рыженко Б.Н., Алексеев В.А., Дутова Е.М., Кондратьева И.А., Копылова Ю.Г., Лепокурова О.Е. Геологическая эволюция и самоорганизация системы вода-порода. Т. 2. Система вода-порода в условиях зоны гипергенеза. Новосибирск: Изд-во СО РАН, 2007. 389 с.].

Tardy Y., 1969. Géochimie des Altérations. Études des Arénes et des Eaux de Quelques Massifs Cristallins d’Europe et d'Afrique. Strasbourg, $199 \mathrm{p}$.

Tardy Y., 1993. Pétrologie des Latérites et des Sols Tropicaux. Masson, Paris, 460 p.

Upadhyay D., 2012. Alteration of plagioclase to nepheline in the Khariar alkaline complex, SE India: Constraints on metasomatic replacement reaction mechanisms. Lithos 155, 19-29. https://doi.org/10.1016/j.lithos.2012.08.010.

Vernadsky V.I., 2003. The History of Natural Waters. Nauka, Moscow, 751 p. (in Russian) [Вернадский В.И. История природных вод. М.: Наука, 2003. 751 с.].

Yanshin A.L., 1993. The emergence of the problem of evolution of geological processes. In: A.L. Yanshin (Ed.), Evolution of Geological Processes in the Earth History. Nauka, Moscow, p. 9-20 (in Russian) [Яншин А.Л. Возникновение проблемы эволюции геологических процессов // Эволюция геологических процессов в истории Земли / Ред. А.Л. Яншин. М.: Наука, 1993. С. 9-20].

Zhang L., Lüttge A., 2009. Theoretical approach to evaluating plagioclase dissolution mechanisms. Geochimica et Cosmochimica Acta 73 (10), 2832-2849. https://doi.org/10.1016/j.gca.2009.02.021.

Zhu C., Lu P., 2009. Alkali feldspar dissolution and secondary mineral precipitation in batch systems: 3. Saturation states of product minerals and reaction paths. Geochimica et Cosmochimica Acta 73 (11), 3171-3200. https://doi.org/10.1016/j.gca.2009.03.015.

Zhu C., Lu P., Zheng Z., Ganor J., 2010. Coupled alkali feldspar dissolution and secondary mineral precipitation in batch systems: 4. Numerical modeling of kinetic reaction paths. Geochimica et Cosmochimica Acta 74 (14), 3963-3983. https://doi.org/10.1016/j.gca.2010.04.012.

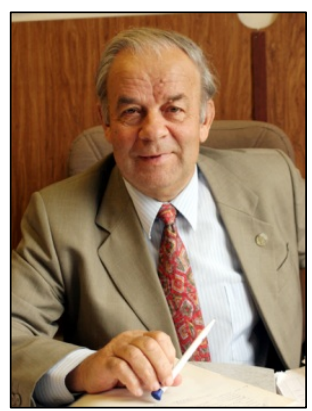

Степан Львович Шварцев, докт. геол.-мин. наук, профессор, г.н.с.

Томский филиал Института нефтегазовой геологии и геофизики им. А.А. Трофимука СО РАН 634055, Томск, пр. Академический, 4, Россия

Национальный исследовательский Томский политехнический университет 634050, Томск, пр. Ленина, 30, Россия

e-mail: tomsk@ipgg.sbras.ru

Stepan L. Shvartsev, Doctor of Geology and Mineralogy, Professor, Chief Researcher

Tomsk Division of A.A. Trofimuk Institute of Petroleum Geology and Geophysics, Siberian Branch of RAS 4 Academichesky ave., Tomsk 634055, Russia

Tomsk Polytechnic University 30 Lenin ave., Tomsk 634050, Russia 